DOI: $10.15290 / \mathrm{bsl} .2014 .05 .08$

\author{
Anna Wieczorkiewicz \\ Uniwersytet Warszawski \\ e-mail: anna.wieczorkiewicz@uw.edu.pl
}

\title{
Hermann Hesse i jego magiczne mosty
}

„Nie dotarłem do Indii statkiem ani pociągiem. Musiałem samodzielnie odnaleźć magiczne mosty" ${ }^{1}$ - pisał Hermann Hesse. Jeśli chodzi o ścisłość (tę geograficzną), to Hesse w ogóle nie był w Indiach. Morska podróż, którą przedsięwziął w roku 1911, z przystankami na Cejlonie, w Singapurze, na wyspie Penang, na Sumatrze wyczerpała jego siły. Nie dopłynął na Wybrzeże Malabarskie - pas ziemi na południowo-zachodnim brzegu subkontynentu, gdzie dawniej jego dziadek prowadził działalność misyjną i gdzie na świat przyszła jego matka, a który on sam znał świetnie z opowieści słyszanych w dzieciństwie i z książek, które potem przeczytał.

W swoich zapiskach Hesse nazywać będzie niekiedy tę wyprawę podróżą do Indii, mając na myśli szerszy obraz Azji Południowo-Wschodniej określany jako Hinterindien. Postacie Hindusów i Chińczyków, pojawiające się potem w różnych jego tekstach, to cienie osób spotkanych lub wyobrażonych w czasie tej podróży. Trwała ona zadziwiająca krótko, jeśli weźmie się pod uwagę ilość tych wzmianek o Indiach i Hindusach - od września do grudnia 1911, oczywiście wliczając w to długie dni żeglugi.

Magiczne mosty, które przerzucił, wydawały się kuszące kolejnym pokoleniom: „Kiedy Allen Ginsberg po raz pierwszy wybrał się do Indii, miał przy sobie, jakże by inaczej, Podróż na Wschód. Potem ten gest powtarzali hipi-

1 H. Hesse, Besuch aus Indien, w: Sehensucht nach Indien: literarrische Annährungen von Goethe bis Günter Grass, red. Beena Kade-Luthra, München 2006. Przekład własny autorki artykułu. 
sowscy "wędrowcy dharmy», budujący szałasy przy plażach Goa" 2 - streścił moc ich atrakcji Mirosław Pęczak. Kontrkulturowi marzyciele jechali do Indii geograficznych, a Hesse był współautorem projektów ich podróży. Dotarli na Wybrzeże Malabarskie (tam bowiem leży Goa). Mogliby czuć się rozczarowani, wiedząc, że ich patron nie postawił stopy na subkontynencie...

A może wcale by tak nie było - wszak nie o mapę fizyczną chodziło w tych podróżach.

Nie był w Indiach w wąskim, geograficzno-politycznym sensie, w naszym rozumieniu tego okeślenia. W owym czasie Singapur i Penang wchodziły w skład tzw. Strait Settlement, pozostającego pod władzą brytyjską; status brytyjskiej kolonii miał też Cejlon, natomiast Sumatrą rządzili Holendrzy. Hindusów oczywiście spotkał - stanowili oni widoczną część populacji Penang czy Singapuru, jakkolwiek jeszcze więcej mieszkało tam Chińczyków (to tych właśnie Chińczyków będzie mógł przywołać w wyobraźni, opisując kulturę chińską).

Był w Indiach w sensie szerokim: duchowym i osobistym. „Kiedy jedenaście lat temu pojechałem do Indii, ujrzałem palmy i świątynie, poczułem zapach kadzidła i drzewa sandałowego, skosztowałem mango i delikatnych bananów, wciąż czułem, że między mną a tym wszystkim jest jakaś zasłona" ${ }^{3}$ - wspominał w niedługim tekście Besuch aus Indien (z niego pochodzi przywołane na wstępie określenie "magiczne mosty"). Przechodząc do konkretów, od razu wskazywał miejsca leżące poza Półwyspem Indyjskim Singapur, Penang czy Cejlon; to tam były owe palmy i świątynie, kadzidła, mango, banany. Jego wyobraźnia od dawna skolonizowana była jednak przez Indie. Jak wspominał, wzrastał w rodzinie, gdzie „[m]odlono się i czytano Biblię, studiowano i uprawiano filologię indyjską, grano dużo dobrej muzyki; wiedziano o istnieniu Buddy i Laozi" ${ }^{4}$. Zapamiętaną z dzieciństwa figurkę indyjską - należącą do wielu orientaliów, posiadanych przez rodzinę - po latach przedstawił jako symbol otwierający przestrzenie sensów, do których dociera się drogą inną niż racjonalne myślenie:

Wychowywali mnie nie tylko rodzice i nauczyciele, lecz również moce wyższe, ukryte i tajemne. Pomiędzy nimi był także bóg Pan, skryty pod postacią tańczącego indyjskiego bożka - jego figurka stała w oszklonej szafce, w gabinecie mojego dziadka. Bóstwo to, pospołu z innymi opiekowało się mną w dzieciństwie na długo przedtem, zanim nauczyłem się czytać i pisać, umysł mój wypeł-

\footnotetext{
2 M. Pęczak, Święte księgi kontestacji, „Polityka”, 7 czerwca 2008.

3 H. Hesse, Besuch aus Indien, s. 154.

4 H. Hesse, Dzieciństwo czarodzieja i inne prozy autobiograficzne, wyb. i przeł. Ł. Jurasz-Dudzik, W. Dudzik, Warszawa 2003, s. 16.
} 
niały odwieczne obrazy i myśli z Wschodu - do tego stopnia, że później każdy kontakt $\mathrm{z}$ indyjskimi i chińskimi mędrcami odbierałem jako spotkanie z czymś dobrze znanym, jako powrót do domu ${ }^{5}$.

Kiedy znalazł się w okolicach Półwyspu Indyjskiego, mógł osadzić w konkretnym habitacie fragmenty opowieści, obrazów i dźwięków, które zapamiętał $\mathrm{z}$ domu rodzinnego - były one dla niego tajemnymi znakami form życia duchowego, domagającymi się uwagi, zapraszającymi do podjęcia wysiłku poszukiwań.

Günter Baumann, autor eseju Hermann Hesse and India, nazwał tamten pierwszy, dziecięcy etap obcowania Hessego z Indiami bezrefleksyjnym (po nim nastąpić miały jeszcze dwa inne etapy - intelektualnego poszukiwania oraz doświadczenia wewnętrznego). Trwał on aż do czasu przeprowadzki pisarza do Gaienhofen w roku $1904^{6}$. Orientalne sympatie rodziców, ich znajomość kultur i języków Wschodu miały, jak zauważa Baumann, swoje granice. Ani hinduizm, ani buddyzm nie były ich wyznaniem - monopol na prawdę miało chrześcijaństwo, będące $\mathrm{w}$ ich odczuciu jedyną prawdziwą religią. Hesse $\mathrm{z}$ niechęcią wspominał zapamiętane $\mathrm{z}$ dzieciństwa praktyki religijne ${ }_{(,}[\ldots]$ niedzielne nabożeństwa, lekcje religii przed konfirmacją, nauka religii, na którą uczęszczałem jako dziecko, nie wywoływały u mnie żadnego przeżycia" 7 ); religijne wychowanie traktował jako formację, którą trzeba było przezwyciężyć (nawet jeśli po latach odzyska się ją ponownie i zaakceptuje jako część własnej duchowości).

Kiedy Hesse opuścił dom rodzinny, Orient w jego życiu na jakiś czas przycichł, by wrócić inną ścieżką, poprzez dzieła zachodnich filozofów. Zwłaszcza pisma Schopenhauera, jego idea świata jako wyobrażenia i silne reminiscencje buddyjskie, niosły $\mathrm{w}$ sobie przesłanie kierujące Hessego ku myśli Wschodu. Sięgnął wtedy na nowo po święte teksty hinduskie. Tak rozpoczął się etap intelektualnych poszukiwań. Potem nastąpiła owa "podróż do Indii" - w krąg kultury azjatyckiej. Hesse odbył ją w towarzystwie swego przyjaciela, malarza Hansa Sturzenggera. Ich pomysł w zasadzie nie był oryginalny, wpisywał się w ówczesną modę na orientalne podróże (i na relacjonowanie ich w książkach ${ }^{8}$. Dla Hessego droga ta wiodła także w świat wyobrażeń z dzieciństwa i w obszary własnej genealogii. Czterdzieści lat wcześniej do Indii wyruszał jego ojciec Johannes Hesse - jechał z polecenia

\footnotetext{
5 Tamże, s. 9.

6 G. Baumann, Hesse and India, www.gss.ucsb.edu/projects/hesse/papers/baumann-hesseand-india.pdf [dostęp 01.06.2014].

7 H. Hesse, Moja wiara, wyb. i posł. S. Unseld, przeł. R. Reszke, Warszawa 1998, s. 69.

8 B. Zeller, Hermann Hesse, przeł. E. Hygen, H. Pinzenöhler, Warszawa 2001, s. 73.
} 
Misji Bazylejskiej. Tam poznał Marię, swą przyszłą żonę, córkę misjonarza Hermanna Gunderta.

Podróż ta - jak wyznawał Hesse we wspomnieniach - była ucieczką od niepokojów Europy, od jej kultury o kakofonicznym brzmieniu, a także do tego nie przyznawał się już tak otwarcie - od kłopotów osobistych (jego pierwsze małżeństwo weszło już wówczas w fazę głębokiego kryzysu). Była to jednak nie tylko ucieczka od, ale i droga do; rewers uciekania stanowiło poszukiwanie:

Nie posiadłem hinduskiego ducha, jeszcze go nie znalazłem, wciąż go szukałem. Dlatego wciąż uciekałem z Europy - ta podróż była ucieczką od znienawidzonego gwaru, krzykliwego bezguścia, jarmarczności, niepokojów i drażniącego hedonizmu'.

Rejs z Genui do Indochin był długi i męczący. We wspomnieniowych obrazkach, które Hesse opublikował wkrótce po powrocie, w roku 1913, daje się odczuć mozół podróży i gęstość czasu spędzonego na morzu. Zbiór Aus Indien rozpoczyna się opowiadaniem, świetnie oddającym tę atmosferę, o nocy spędzonej na Kanale Sueskim:

Od dwóch godzin na statku dokuczają komary. Panuje upał; zadziwiająco szybko skończył się przyjemny klimat śródziemnomorski; wiele osób obawia się tego niesławnego gorąca na Morzu Czerwonym. [...] Próbuję zasnąć. Kładę się na koi w maciupkiej kabinie, nade mną warkocze wiatrak, w okrągłym okienku granatowa czerń gorącej nocy, słychać szelest moskitów. Tak spokojnej nocy nie mieliśmy od Genui. Od wielu już godzin nie dobiegały już żadne odgłosy, gdy na odległym pasie nasypu pojawił się pociąg z Kairu; jak upiór przetoczył się, sapiąc, po czym $w$ magiczny sposób zniknął $\mathrm{w}$ dalekich trzcinach rozległego krajobrazu.

Nim zdążę zasnąć, niepokój mój wzbudza nagłe zamilknięcie silnika. Stoimy w ciszy. Ubieram się i wychodzę na górny pokład. Wokół niebywała cisza, znad Synaju nadciąga ubywający księżyc, w sunącym blasku reflektora widać odległe góry piasku, martwe i matowe; w nieskończonej czarnej tafli wody odbijają się jaskrawe refleksy, a pod ciężkim, matowym księżycem setki mórz, jezior, zarośniętych stawów - zółtych i obojętnych na tych ponurych równinach. Nasz statek już nie płynie, żadnych dźwięków, syren - tkwi nieruchomy, jak zaczarowany, a jednak rzeczywisty na tym pustkowiu ${ }^{10}$.

Na Sumatrę z Singapuru Hesse płynie niewielkim statkiem holenderskiej żeglugi przybrzeżnej, do Palembang w południowej części wyspy przedostaje się chińskim parowcem. W narracyjnych obrazkach czuje się perypatetyckiego ducha tej podróży. Hesse opowiada o tym, jak płynie, spaceruje, jedzie

9 H. Hesse, Besuch aus Indien, s. 154.

${ }^{10}$ H. Hesse, Aus Indien, Berlin 1919, s. 9-10. 
rikszą, wspina się na górę... Nie zna języka, ale rozgląda się, szuka znaczących widoków - wyobraźnia rozwinie je w impresyjne narracje. Próbuje okazjonalnie zadomawiać się $w$ tym środowisku, traktując je jako miejsce tymczasowej codzienności. (,W Singapurze znowu odwiedziłem teatr malajski - nie po to, by zapoznać się ze sztuką czy folklorem, nie po to, by poszerzyć swą wiedzę, ale zwyczajnie, by miło spędzić czas, tak jak czyni to człowiek $\mathrm{w}$ czasie wolnym $\mathrm{w}$ nieznanym sobie nadmorskim mieście: po kolacji i kawie nabiera ochoty na przestawienie w Variette"11 - pisze w opowiadaniu Der Hanswurst). Z zapałem impresyjnego dokumentalisty szkicuje szybkie obrazki: jedenastoletnia Chinka z obnośnym straganikiem, singapurski warsztat, gdzie wyplata się ratanowe meble, dzieciaki biegnące za rikszą, którą jedzie cudzoziemiec... (opowiadanie Augenlust). Z uwagą stara się oddać nastrój: Kandy w atmosferze przedłużającej się pory deszczowej, ciężkie chmury, tropikalny krajobraz spowity szarością - podobnej tej z późnojesiennego Schwarzwaldu... (opowiadanie Spaziergang in Kandy).

Z czasem konkretności nabierają ogólnie rozumiane "Indie” jako miejsce podróży legitymizującej wiedzę autora-filozofa. Przekształca się też sensorium podróżnika. W zbiorze Aus Indien wspomniana jest radość, jaką po niewygodnych nocach spędzonych na pokładzie daje wygodne łóżko w hotelu $\mathrm{w}$ Penang. $\mathrm{W}$ nieco późniejszym Besuch aus Indien na plan pierwszy wybija się zapach kadzideł i smak mango, znakujące tę podróż fragmentami bardziej azjatyckich doznań sensualnych. Myśl wędruje coraz szybciej, czyniąc szybkie zestawienia, zdolna zaczerpnąć z repozytorium „indyjskiej podróży”. W roku 1960 Hesse będzie wspominał: „Kiedy przed pięćdziesięciu laty byłem w Indiach, na całym Wschodzie biały człowiek uchodził jeszcze za pana «tubylców» i «kolorowych» [podkr. - A.W.]"12. Narracja kołuje - opowieść krąży po Azji Południowo-Wschodniej, zabiera nas do Indii, a właściwie do Indochin, zbliża się do tamtejszych wysp, po czym osiada w miejscu „obserwacji terenowych". Po wprowadzeniu czytelników w atmosferę Orientu, autor przechodzi do konkretów umiejscowionych na Jawie i Sumatrze ${ }^{13}$, a następnie opisuje to, co jemu samemu się przydarzyło:

11 Tamże, s. 33.

12 H. Hesse, Moja wiara, s. 61.

13 Np.: „Wśród kolonistów i kupców europejskich było niewielu ludzi, którzy trochę się interesowali indyjską lub chińską architekturą, malajską sztuką batiku, językami, religiami i dawnymi zwyczajami ludów tubylczych. Zbierali wiec chińską porcelanę, jawajskie posążki wajang i mieli otwarte oczy na piękno natury tamtejszych stron. Na Jawie i na Sumatrze nawet wśród urzędników kolonialnych było kilku, którzy w latach swej młodości przepadali za Multatuli, lecz oni również nie potrafili przełamać barier, które - jako białych i panów dzieliły ich od tubylców" [podkr. - A.W.] (Tamże, s. 61). 
Nigdy nie zapomnę drobnego incydentu, który miał miejsce podczas mojej wizyty na Sumatrze.

Kilka dni mieszkaliśmy w bungalowie pewnej kompanii handlowej, która wysoko przy Batang Hari kupiła kawałek lasu. W bungalowie zakwaterowani byliśmy my - panowie - Europejczycy. W rozsypanych wokół chatach ze trzciny mieszkali malajscy robotnicy leśni - z nimi mieszkał również nasz kucharz Chińczyk. Pewnego wieczoru pojawił się u nas nadzorca robotników - przystojny Malajczyk o smutnym wejrzeniu; wieść niosła, że to człowiek szlachetnego rodu, syn wodza ${ }^{14}$.

Opowieść ta ma ukazać specyfikę relacji między białymi i „kolorowymi” (autor zostaje poinformowany o tym, że zwracając się do Malaja, nie przestrzegał przyjętych form i zbytnio się z nim zbratał). Spośród owych „kolorowych” Hesse zauważa jednak przede wszystkich Hindusów i Chińczyków - to oni szczególnie go interesują:

Ludy kolorowe, od których najwięcej się nauczyłem i wobec których żywię największy respekt, to Hindusi i Chińczycy. Oba te narody stworzyły kulturę duchową i artystyczną, która góruje nad naszą wiekiem, gdy zaś chodzi o treść i piękno - jest ona równie wartościowa ${ }^{15}$.

Hindusów - jak wiemy - poznał dawno temu, pośrednio, dzięki atmosferze domu rodzinnego, Chińczyków „odkrył” podczas tej podróży. Sumatrzańskie zdarzenie rozszerza się, generuje rozciągający się układ zależności - pozwala pisać o filozofii, o religii, o polityce.

Wyobraźnia Hessego była tak intensywnie nasycona znakami Orientu, że znalezienie się w Azji i zanurzenie w lokalnym świecie przyniosło mu rozczarowanie. „W Kandy, pośród buddyjskich kapłanów, miałem w sobie tę samą niezaspokojoną tęsknotę za prawdziwymi Indiami, za ich duchem, za żywym dotknięciem, którą odczuwałem w Europie. Czułem tę samą tęsknotę za prawdziwymi Indiami, za ich autentycznym duchem, która przepełniała mnie w Europie, gdy o Indiach marzyłem"16 - pisał w Besuch aus Indien. Sama przez się ta podróż nie zaspokoiła pragnienia duchowości - pokazała jedynie, że szukać trzeba w przestrzeniach własnego wnętrza:

Musiałem przestać szukać tam wybawienia od Europy, musiałem przestać walczyć z Europą w moim sercu, musiałem przyswoić sobie w sercu i duszy prawdziwą Europę i prawdziwy Wschód; trwało to wiele lat, przepełnionych cierpieniem i niepokojem, lat wojny i rozpaczy.

14 Tamże, s. 61-62.

15 Tamże, s. 62.

16 H. Hesse, Besuch aus Indien, s. 154. 
I wtedy zaczęła się nowa epoka - przestałem czuć tęsknotę do palmowych plaż Cejlonu czy ulic Benares, nie chciałem zostać buddystą lub taoistą, mieć za nauczyciela świętego lub czarownika. To wszystko stało się nieważne, nieważna już była różnica miedzy uwielbianym Wschodem a chorym, cierpiącym Zachodem, między Azją a Europą. Już nie pragnąłem zgłębiać jak największej ilości wschodnich mądrości i kultów, poznałem, że tysiące dzisiejszych wyznawców Lao Tse mniej wiedziało o Tao niż Goethe, który nigdy nie słyszał słowa tao. Poznałem, że w Europie i Azji istnieje ukryty ponadczasowy świat wartości i ducha, któremu nie zaszkodził ani wynalazek lokomotywy ani Bismarck, i że dobrze jest uczestniczyć $\mathrm{w}$ tym ponadczasowym świecie, $\mathrm{w}$ tym pokoju duchowego świata, który tworzą w takim samym stopniu Europa i Azja, Wedy i Biblia, Budda i Goethe. Tu zaczęła się moja szkoła magików, która trwa do dziś; ta nauka nie ma końca. Ale z tęsknotą za Indiami i ucieczką przed Europą skończyłem raz na zawsze i dopiero teraz Budda i Dhammapada i Tao-te-king brzmią w sposób czysty i znajomy, i nie mają dla mnie tajemnic ${ }^{17}$.

W ten sposób określony zostaje ów etap obcowania ze Wschodem, który polega na doświadczeniu wewnętrznym; scala ono różne elementy, nawet te, które pozornie wydają się sobie przeciwstawne, tak jak Wschód Zachodowi.

Tę historię odnajdywania w sobie celu poszukiwań Hesse opowiedział w Siddharcie - krótkiej powieści, która ukazała się w roku 1922. Autor nazwał utwór swoim wyznaniem wiary $(1931 \mathrm{r} \text {. })^{18}$, a proces pisania wspominał jako doświadczenie szczególnego rodzaju, jako wchodzenie w indyjskość współkonstytuowane przez elementy medytacyjne:

Doświadczyłem wtedy, oczywiście nie po raz pierwszy, ale dotkliwiej niż kiedykolwiek, że nie ma sensu pisać o czymś, czego się nie przeżyło. Po długiej przerwie, podczas której zrezygnowałem już z pisania powieści Siddhartha, musiałem znów wciągnąć się w medytacje i ascetyczne życie, zanim świat ducha Indii, który już od lat młodości był dla mnie święty i duchowo pokrewny, mógł stać się dla mnie znowu ojczyzną ${ }^{19}$.

Wprawdzie, jak zaznaczają niektórzy badacze, powieść ta tchnie raczej duchem taoistycznym, a sztafaż hinduski to jedynie jej powierzchnia ${ }^{20}$. Dla

\footnotetext{
17 Tamże, s. 155.

18 Zob.: „Wyznanie wiary składałem nie tylko od czasu do czasu w okazjonalnych artykułach, kiedyś bowiem - nieco ponad dziesięć lat temu - podjąłem próbę złożenia credo w książce. Książka nosi tytuł Siddhartha, zaś treść wyłożonej w niej wiary części, badali i dyskutowali hinduscy studenci i japońscy kapłani - ich chrześcijańscy koledzy nie potrafili się na to zdobyć" (H. Hesse, Moja wiara, s. 67).

19 Cyt. za: B. Zeller, Hermann Hesse, s. 105.

20 B. Zeller, Hermann Hesse, s. 107; J. Prokopiuk, Hermana Hessego spirala życia, w: H. Hesse, Podróż na Wschód, Warszawa 1991, s. 85.
} 
autora jednak ów sztafaż miał niebagatelne znaczenie, będąc jednocześnie formą wyrazu i treścią, niedającą się ująć w słowa:

Fakt, że moja wiara $\mathrm{w}$ tej książce ma hinduskie imię i hinduskie oblicze, to bynajmniej nie przypadek. Religię przeżywałem $w$ dwóch formach: jako syn i wnuk pobożnych, poczciwych protestantów oraz jako czytelnik hinduskich objawień, spośród których pragnąłbym wymienić zwłaszcza Upaniszady, Bhagawadgitę i mowy Buddy. [...] Tak oto już od dziecka oddychałem duchową atmosferą hinduizmu i chrześcijaństwa - przeżywałem i jedno, i drugie ${ }^{21}$.

Fabuła Siddharthy jest prosta, jednowątkowa, czyta się ją jak przypowieść wiodącą do zrozumienia prawdy, sytuującej się ponad planem przedstawionym. Indyjską przestrzeń, w której toczą się wydarzenia, naszkicowano bardzo umownie - jej obraz zawiera się już w pierwszym zdaniu: „Siddhartha dorastał w cieniu rodzicielskiego domu, w słońcu nad brzegiem rzeki, gdzie kołysały się łodzie, cienie lasu, w cieniu drzewa figowego" ${ }^{22}$. Rzeka, las, dom, a także miasto czy droga mają wartość symboliczną; do nich ogranicza się topografia przestrzeni. Symbole pojawiają się, by wskazać na ogólniejsze sensy, nie są potrzebne ich opisy; ważna jest opowieść o rozwoju wewnętrznym.

Siddhartha to potomek bramińskiego rodu, który opuszcza rodzinę, by szukać oświecenia wśród wędrownych ascetów. Droga nie prowadzi go jednak tam, gdzie się spodziewał, nie wiedzie prosto ku oświeceniu. Po rozmowie z Gautamą Buddą młodzieniec decyduje się zejść z tej ścieżki i zanurzyć w życiu, które zdaje się toczyć gdzieś obok. U boku pięknej kurtyzany Kamali poznaje świat wyrafinowanej zmysłowości. Wcześniej jeszcze, by zyskać jej względy, musi zdobyć bogactwo, co czyni, zostając kupcem. Z czasem zaczyna odczuwać pustotę tego życia i je porzuca. Rozważając swe postępki, nie uważa jednak zmysłowego dotknięcia świata za bezsensowne. Przebyta droga - choć wiedzie zakolami - zdaje się prowadzić go do celu:

Czyż nie jest tak, że powoli, okrężna drogą w wieku męskim doszedłem do niedojrzałości, myśliciel stał się dzieckiem? A jednak była to dobra droga, a jednak ptak w mojej piersi wciąż żyje. Dziwna, doprawdy, droga! Trzeba było przedrzeć się przez tyle głupoty, tyle występków, tyle błędów, tyle odrazy, rozczarowań i nieszczęścia, tylko po to, by na koniec znowu stać się dzieckiem i móc zacząć od nowa. Ale droga była słuszna, moje serce jej przytakuje, oczy się do niej śmieją ${ }^{23}$.

\footnotetext{
${ }^{21}$ H. Hesse, Moja wiara, s. 67-68.

22 H. Heese, Siddhartha, przeł. M. Łukasiewicz, Poznań 1988, s. 7.

23 Tamże, s. 80-81.
} 
Zakole, krąg, powrót, to motywy, które powtarzają się w tej opowieści, ale ich sens konstytuuje się $\mathrm{w}$ powiązaniu $\mathrm{z}$ innym motywem - wciąż płynącej rzeki. To właśnie nad rzeką, u boku prostego przewoźnika decyduje się zostać Siddhartha:

\begin{abstract}
Zostanę nad tą rzeką, myślał Siddhartha, to ta sama rzeka, przez którą się przeprawiałem $w$ drodze do ludzi-dzieci. Przewoźnik okazał mi wtedy tyle przyjaźni, pójdę do niego, kiedyś z jego chaty moja droga powiodła mnie ku nowemu życiu, które teraz zestarzało się i umarło - niech moja teraźniejsza droga, niech moje nowe życie rozpocznie się $\mathrm{w}$ tym samym miejscu! ${ }^{24}$
\end{abstract}

Przewoźnik uczy Siddharthę wsłuchiwać się w głos rzeki, mówi, jak chwytać uchem jej śmiech. Nad rzeką zjawia się Kamala - jest w pielgrzymiej wędrówce wraz ze swym synkiem, urodzonym już po odejściu Siddharthy. Kamala umiera nagle ukąszona przez żmiję; przedtem jednak przekazuje Siddharcie wiadomość o jego ojcostwie. Siddhartha ma okazję doznać ludzkiej, przejmującej miłości do dziecka. Dziecko jednak nie chce jego poświęcenia, dobroci, nauk, w końcu odchodzi. Ojciec musi zaprzestać prób sprowadzenia go do domu. Zostaje nad rzeką - a ona uczy go głębokiej medytacji. Medytacyjne zatapianie się $\mathrm{w}$ odgłosach rzeki prowadzi do spełnienia, którego Siddhatha od dawna poszukiwał:

Siddhartha nasłuchiwał. Cały zamienił się w słuch, cały pogrążył się w słuchaniu, cały się otworzył, czuł, że oto zgłębił do końca, czym jest słuchanie. [...] I wszystko razem, wszystkie głosy, wszystkie cele, wszystkie tęsknoty, cierpienia, uciechy, wszelkie dobro i zło, wszystko to razem stanowiło świat. Wszystko razem stanowiło wielką rzekę dziejów, było muzyką życia. I gdy Siddhartha słuchał uważnie rzeki, wsłuchiwał się w rozbrzmiewający tysiącem głosów śpiew, gdy nie szukał w nim już tylko cierpienia ani tylko śmiechu, gdy nie sprzęgał duszy z jakimś jednym głosem i nie wnikał weń swoim ja, ale słyszał wszystko, słyszał całość, słyszał jedność, wówczas wielka pieśń tysiąca głosów stała się jednym jedynym słowem OM - spełnieniem ${ }^{25}$.

To nie koniec tej opowieści - czyni ona kolejne zakole. Nad rzeką zjawia się przyjaciel młodości - Gowinda, z którym Siddhartha niegdyś wyruszył $\mathrm{w}$ drogę. Gowinda nadal pędzi życie wędrownego ascety w poszukiwaniu oświecenia. Zrazu nie rozpoznaje niegdysiejszego towarzysza, potem chce od niego nauki. Wówczas Siddhartha prosi go o złożenie pocałunku na swym czole - to inicjuje niezwykłą wizję Gowindy, a czytelnikom przypomina

\footnotetext{
24 Tamże, s. 84.

25 Tamże, s. 112.
} 
prawdę, która wskazana została znacznie wcześniej, niemal na początku tej opowieści: „nikomu wybawienie nie jest dane przez naukę" ${ }^{26}$, potrzebna jest tajemnica przeżycia.

Podobną myśl Hesse wygłosił w cytowanym już wcześniej tekście Besuch aus Indien. Niedojrzały owoc nie da się otworzyć - pisał wówczas; studiowanie myśli hinduskiej czy chińskiej, obcowanie z przejawami jej ducha, a nawet udanie się do kraju, który je zrodził, samo przez się nie da nam pełnego doświadczenia, musi ono $\mathrm{w}$ nas dojrzeć, tak jak dojrzewa owoc ${ }^{27}$. W innym miejscu pisał:

Jasne, że nie może nam pomóc import ze Wschodu, że nie pomoże nam sięgnięcie do Indii lub Chin ani odwrót do zdefiniowanego w jakiś sposób chrześcijaństwa kościelnego, ale jest równie jasne, że ocalenie, przetrwanie kultury europejskiej możliwe będzie jedynie wtedy, gdy zostanie na nowo odkryta sztuka życia duchowego i duchowe dobro wspólne ${ }^{28}$.

Sugestie o istocie doświadczenia religijnego napływają z Azji, ale oczywiście odebranie sugestii to dopiero początek procesu, który powinien w nas zajść. Płynie ona ze Wschodu, gdyż:

[c]ały Wschód oddycha religią, tak jak cały Zachód oddycha rozumem i techniką. Życie duchowe człowieka Zachodu, porównane ze skrywaną, pielęgnowaną, pełną ufności religijnością Azjaty - buddysty, muzułmanina czy kogo tam jeszcze - wydaje się prymitywne i wystawione na łup przypadku ${ }^{29}$.

Gdzie jednak jest ów „cały Wschód"? Co stanowiło podstawę dla takiego uogólnienia? Składa się na nie z pewnością to, co Hesse przeczuwał od dzieciństwa dzięki orientaliom, wśród których wzrastał, to, co potem przeczytał i w końcu to, czego doświadczył w czasie swej azjatyckiej podróży. To ostatnie źródło wiedzy miało dla niego szczególną wartość:

\footnotetext{
26 Tamże, s. 198.
}

27 Hesse zaznaczał jednak, że postępując drogą z Zachodu na Wschód nie stajemy się ludźmi Wschodu: „Modna dama, która obok brązowej statuetki Buddy przywiezionej z Cejlonu lub Syjamu kładzie teraz trzy tomy z mowami Oświeconego, równie daleka jest od tej drogi, jak ów asceta, który z powodu nędzy jałowej codzienności sięga po opium dogmatycznego buddyzmu. Jeśli wiec my - ludzie Zachodu - wreszcie choć trochę nauczymy się medytować, to osiągniemy inne rezultaty niż Hindusi. Medytacja nie stanie się dla nas opium, lecz umożliwi pogłębione samopoznanie - czyli to, czego greccy mędrcy wymagali od swych uczniów jako ich najpierwszego, najświętszego obowiązku (H. Hesse, Moja wiara, s. 34-35).

28 H. Hesse, Moja wiara, s. 102.

29 Tamże. 
To, czy religia jest tym, co może się przeżyć i zostać zastąpione, niechże pozostanie w sferze pytań, ale fakt, że religia - lub to coś, co może ją zastąpić - jest tym, czego najbardziej nam brak, nigdy nie ujawnił mi się z tak bezlitosną jasnością jak wówczas, gdy przebywałem wśród ludów Azji [podkr. - A.W.] ${ }^{30}$.

Pytanie - co znaczy owo "przebywanie wśród ludów Azji” - nasuwa się samo. Wiemy, jak krótko Hesse przebywał w Azji, wiemy, że nie znał tubylczych języków i że z pewną niesprawiedliwością obdzielał uwagą azjatyckich "kolorowych" - pozwolił, by Hindusi i Chińczycy rozrośli się w wielkie egzemplaryczne figury, a Malajowie, Tamilowie, Synegalezi odsunęli na dalszy plan.

O specyfice "przebywania wśród ludów Azji” niewiele powiedzą przywoływane okazjonalnie przykłady z „pobytu w Indiach” rozsiane po różnych tekstach. Nie powie nam tego przypowieść Siddhartha, która była dla autora eksperymentem medytacyjnym, ani późniejszy Życiorys hinduski (zamykający powieść Gra szklanych paciorków). Te przypowieści w sterylny sposób ukazują pewne sensy postępowania duchową ścieżką. W Życiorysie hinduskim zwraca jednak uwagę żywe wspomnienie zachwytu egzotyczną przyrodą. Topografia w zasadzie pozostaje tu niemal równie umowna, jak w Siddharcie. Pałac, miasto, wieś zdają się nie mieć wyglądu - symbolizują pewien rodzaj życia, są implikowane przez bieg narracji. Jest jednak kilka fragmentów, gdy ów bieg na chwilę staje, zatrzymany rozkwitem bujnej przyrody. Jej obrazy mogą być różnie wystylizowane. $W$ epizodzie dorastania książęcego syna Dasy w lesie wśród pasterzy fantazyjny las malowany jest jakby pędzlem prymitywisty:

poznał las, wraz z jego drzewami i owocami polubił mango, figę leśną i drzewo varinga, wyławiał słodkie korzenie lotosu z zielonych leśnych sadzawek, w dni świąteczne nosił wieniec z czerwonych kwiatów leśnego płomienia, uczył się od zwierząt $\mathrm{w}$ głuszy ostrożności, unikania tygrysa, przyjaźni $\mathrm{z}$ mądrym mungo i wesołym jeżem, a przeczekiwania pory deszczowej $\mathrm{w}$ mrocznym szałasie $[\ldots]^{31}$.

W urywku o wyprawie chłopca po miód impresjonistyczny, świetlisty obraz tropików błyskawicznie rozrasta się w żyjącą przestrzeń - otaczającą widza bogactwem form i kolorów, oszołamiającą zapachami, rozedrganą dźwiękami, ruchliwą, a jednocześnie trwającą, niezmienną:

\footnotetext{
30 Tamże.

31 H. Hesse, Życiorys hinduski, w: Gra szklanych paciorków, przeł. M. Kurecka, Warszawa 1999, s. 627.
} 
światło przebijało się przez gałęzie i liście jak złociste węże, a podobnie jak dźwięki, głosy ptaków, poszum wierzchołków drzew, krzyki małp, splatały się w uroczą, łagodnie świetlistą wiązankę, przypominającą przebłyski światła wśród zieleni, nadpływały też, łączyły się i znowu rozłączały zapachy, wonie kwiatów, drewna, liści, wód, mchów, zwierząt, owoców, ziemi i zgnilizny, ostre i słodkie, dzikie i znajome, orzeźwiające i usypiające, żywe i dławiące. Od czasu do czasu w niewidzialny leśnym wąwozie zaszumiała woda, nad kielichami białych kwiatów zatańczył aksamitnie zielony motyl, o skrzydłach ozdobionych czarnymi i żółtymi plamami, trzasnęła gałąź, gdzieś głęboko, w błękitnym cieniu zarośli ciężko opadł liść, w ciemności zaryczał zwierz dziki lub krzykliwa małpa toczyła spór, jazgocząc ze swoimi ${ }^{32}$.

Ogólnie jednak rzecz biorąc, w „indyjskich” fragmentach twórczości Hessego gęstość doświadczenia podróży rozmywa się, niknie jego wymiar zmysłowy. Dzieje się tak nawet w wtedy, gdy mowa jest o przemieszczaniu się - statkiem, łodzią, rikszą, piechotą (sporo takich sytuacji zwłaszcza w zbiorze Aus Indien). Jest jednak pewien tekst, który wprowadzić nas może w to, co zadziało się pomiędzy pragnieniem osadzenia „orientaliów" w ich habitacie a pewnością pisarza, mającego na podorędziu orientalne exempla.

Opowiadanie Robert Aghion napisane w roku 1912, a opublikowane rok później (włączone w zbiór Aus Indien) można czytać jako pogłębioną analizę doświadczania indyjskości in situ. Akcję Hesse odsuwa w przeszłość - na koniec XVII wieku, kiedy to Indie zdawały się znacznie odleglejsze od Europy niż w jego epoce:

W owych czasach podróżujący do Indii nie docierali do celu tak niedoświadczeni jak dziś kiedy pasażer wsiada w Europie na wygodny parowiec, wymija Afrykę Kanałem Sueskim i po krótkim czasie, rozleniwiony obfitością snu i jedzenia, dostrzega ze zdumieniem brzegi Indii. Wówczas trzeba było miesięcy, by żaglowy statek okrążył olbrzymi kontynent Afryki, zdarzały się groźne burze i chwile paraliżującej bezwietrznej pogody, nieraz przychodziło dobrze się napocić i namarznąć, głodować i nie dosypiać, a kto zwycięsko pokonał trudy podróży, nie był już żółtodziobym nowicjuszem, ale człowiekiem doświadczonym i zdolnym poniekąd stać na własnych nogach. Tak też było z misjonarzem. Spędził sto pięćdziesiąt sześć dni na morzu i w porcie bombajskim opuścił pokład statku jako ogorzały i wychudzony wilk morski ${ }^{33}$.

\footnotetext{
32 Tamże, s. 628.

${ }^{33}$ H. Hesse, Robert Aghion, w: tegoż, W słońcu dawnych dni, przeł. M. Łukasiewicz, Poznań 1988, s. 102-103.
} 
W ten sposób intensyfikacji ulega opowieść o podróży, zawierającej w sobie mozół trwania, wymuszającej bezruch - podróżny ograniczony powierzchnią pokładu czeka, aż statek zawinie do portu. Tym szlakiem płynął jeszcze dziadek Hessego, Hermann Gundert, gdy w wieku lat 22 udawał się na misję. Czas spędzony na statku wykorzystywał na naukę języków, które niewątpliwie mogły mu się przydać $\mathrm{w}$ indyjskim posłannictwie, ale które też same w sobie stanowiły dla niego fascynujący świat - zwiedzał zatem bengali, hindustani, telugu... Fascynacje lingwistyczne towarzyszyć mu będą przez całe życie (jego badania nad językiem malajalam do dziś zachowały wartość).

Podróżnym, przywołanym do życia przez Hessego we wspomnianym opowiadaniu, jest Robert Aghion - młody duchowny anglikański, który odpowiedział na ofertę pewnej fundacji wysyłającej misjonarzy do Indii. Choć jego wiara jest szczera, to nie pragnienie jej krzewienia było bodźcem do podjęcia wyprawy, a chęć ujrzenia azjatyckiej przyrody - szczególnie tamtejszych motyli. Z czasem rozwinie $w$ sobie także zainteresowanie językiem hindi.

Hesse tak skonstruował tę postać, że wydobyty został moment oddziaływania Indii na Europejczyka - oddziaływania zmysłowego, niedającego się zamknąć w słowach, ewokującego cień jakiejś tajemnicy. Samotność fizyczna i emocjonalna Aghiona, jego otwartość na nowe doświadczenia, zdolność spontanicznego zachwytu czynią go bezbronnym wobec przejawów działania tego świata - ale też nie chce się on przed nimi bronić. $Z$ pewnością jest $\mathrm{w}$ Aghionie trochę $\mathrm{z}$ dziadka Gunderta, trochę $\mathrm{z}$ Hessego, ale nie jest on jedynie ich porte parole. Zrazu wydaje się, że to podróżnik w typie oświeceniowym, przed-Whitmanowskim. Jego fascynacja przyrodą skojarzona jest z praktyką kolekcjonerstwa, regulującą stosunek do przedmiotu fascynacji. Widząc pięknego motyla, przyrodnik zachwyca się jego urodą, chwyta w siatkę, by potem przebić szpilką i umieścić w kolekcji będącej wizualną reprezentacją porządku klasyfikacyjnego ${ }^{34}$. Potrafi uruchomić imperialistyczne spojrzenie, które $\mathrm{w}$ oglądanych krajobrazach widzi zasoby ekonomiczne ${ }^{35}$. Jego podejście do pracy ewangelizacyjnej zdominowane jest przez metodyczny program poznawczy:

34 Zob.: „Kiedy po raz pierwszy zamachnął się siatką na wielkiego, wspaniałego motyla, kiedy go schwytał i ostrożnie ujął palcami przepyszne w swej urodzie stworzenie, którego skrzydła miały blask alabastru i owiane były wonnym, barwnym pyłkiem, serce zabiło mu niepohamowaną radością, jakiej nie zaznał od czasów, gdy jako dziecko schwytał pierwszego w swym życiu pazia królowej" (Tamże, s. 112).

35 Odwołuję się tu do koncepcji Mary Louise Pratt. (M.L. Pratt, Imperialne spojrzenie. Pisarstwo podróżnicze a transkulturacja, przeł. E.E. Nowakowska, Kraków 2011. 
Starał się poznać życie, pracę i dochody tubylców, kazał sobie pokazywać i nazywać drzewa i owoce, zwierzęta domowe i sprzęty, zagłębiał się w tajniki mokrej i suchej uprawy ryżu, obserwował obróbkę trzciny i bawełny, patrzył, jak buduje się domy, robi garnki, wyplata kosze i tka, które to czynności zna z rodzinnych stron. Przyglądał się, jak tłuste woły czerwonej maści orzą ilaste pola ryżowe, poznawał pracę oswojonych słoni i widział, jak posłuszne małpki przynoszą swoim panom owoce $\mathrm{z}$ drzewa kokosowego ${ }^{36}$.

Zresztą na początku opowiadania Hesse ukazuje ewangeliczną misję wśród pogan jako element działań kolonizacyjnych, związanych z imperialnym porządkiem i planem eksploatacji podbijanych ziem. Przy końcu tej historii jej bohater decyduje, że nie będzie misjonarzem, wybiera zajęcie wpisujące się w tę samą koncepcję opanowywania świata: zatrudnia się jako sekretarz i nadzorca na pobliskiej plantacji kawy. (,Jego powołaniem było podbić ten kraj dla siebie oraz dla innych, wyciągnąć stąd jak najwięcej pożytków, zaprzęgając do dzieła oczy, wiedzę, rwącą się do czynu młodość i gotowość podjęcia każdej nadarzającej się pracy" ${ }^{37}$ ).

Zanim to się stanie, obserwujemy proces, który wcale nie polega na "podbijaniu kraju dla siebie" - to raczej kraj oddziałuje na misjonarza na różne sposoby i bierze go w swoje posiadanie. Robert zdaje się nie mieć warstwy ochronnej, którą europejscy kolonizatorzy, urzędnicy mieszkający $\mathrm{w}$ Indiach tworzyli $\mathrm{z}$ gestów, obyczajów, relacji towarzyskich nawiązywanych we własnym gronie; doznaje nowego kraju każdym nerwem - a my jak w laboratorium, na wyizolowanym preparacie, obserwujemy, co dziać się może z Europejczykiem w środowisku azjatyckim, w przestrzeni rozkwitłej bujną przyrodą, zmieniającej się wraz z porami dnia, rozbrzmiewającej dźwiękami, ruchliwej, z immanentnie wpisanym w nią środowiskiem ludzkim. Ciało Europejczyka porusza się $w$ tej przestrzeni niezręcznie, wciąż napotyka jej opór. Nie sposób usiąść ze skrzyżowanymi nogami, trzymając prosto kręgosłup; ryż z baraniną przyprawiono palącym curry. Język męczy się, próbując prawidłowo wymówić dźwięki hindi. Trzeba troszczyć się o to europejskie ciało, wpisując w rutynę dnia nieznane wcześniej strategie - pod nogi stołu i łóżka podstawia się miseczki z wodą dla ochrony przed mrówkami; wchodząc do pomieszczenia warto rozejrzeć się, czy nie czai się gdzieś wąż, a w razie potrzeby należy szybko go zatłuc. Czasem, gdy Europejczyk chce dotknąć rzeczywistości, ona się uchyla; z reguły dotyczy to kontaktu ze światem ludzi (młodzieniec uczący Aghiona hindi „mówił nieźle po angielsku i miał doskonałe maniery; spłoszył się tylko i cof-

\footnotetext{
${ }^{36}$ H. Hesse, Robert Aghion, s. 115.

37 Tamże, s. 124.
} 
nął, gdy Anglik w najlepszej wierze na powitanie wyciągnął doń przyjaźnie rękę, a również w przyszłości unikał wszelkiego kontaktu cielesnego z białym - dla Vyardenyi, który należał do wyższej kasty, kontakt taki oznaczałby skalanie" 38 ).

W Besuch aus Indien Hesse wspominał o zasłonie, która zdawała się oddzielać go od rzeczywistości i - mimo iż znalazł się w miejscu tchnącym azjatycką duchowością - nie udostępniła tego, czego poszukiwał. To opowiadanie ukazuje gęstość tej zasłony.

Aghiona bardziej interesuje świat natury niż społeczność ludzka. Tubylcy są dla niego częścią przyrody - patrzy na nich jak na element krajobrazu, dlatego może przyjąć, że ludzi właściwie nie widuje ${ }^{39}$. Inaczej niż autor, który powołał go do życia, niewiele wie o Indiach, a one apelują do niego z niezwykłą siłą. Idąc gdzieś w ważnych jakoby sprawach, chwyta kątem oka rój białych motyli unoszących się nad krzewem o ciemnych liściach, zauważa jego wielkie, złocistożółte kwiaty; spostrzega nagie piersi pięknych kobiet i pełne erotyki rzeźby zdobiące świątynie; podąża za dźwiękiem bębnów i kotłów, wiodących do barwnej świątyni. Zanurzony w indyjskim świecie, odbiera go zmysłami, ale go nie pojmuje - i wtedy zaczyna słyszeć apel duchowości. Świątynia, do której trafia, zdaje się jakimś bytem samym w sobie, wciąga go w obszar swego działania:

Szaleńcza muzyka rozbrzmiewała wciąż jeszcze, teraz już całkiem niedaleko; jakoś za rogiem najbliższej uliczki znalazł to, czego szukał. Stała tam przedziwna budowa o fantastycznych formach i zatrważającej wysokości, z olbrzymią bramą pośrodku, a gdy spojrzał w górę, zobaczył, że całą gigantyczną fasadę budynku zapełniają kamienne postacie bajecznych zwierząt, ludzi i bogów albo demonów, piętrzące się setkami aż po strzelisty wierzchołek świątyni; las, dziki gąszcz ciał, kończyn i głów. Ten przerażający kolos z kamienia, wielka świątynia hinduska błyszczała jaskrawo w poziomych promieniach zachodzącego słońca i zdumionemu przybyszowi mówiła wyraźnie, że ci łagodni jak zwierzątka, półnadzy ludzie nie są bynajmniej rajskimi dziećmi natury, ale od tysięcy lat już umieją myśleć, mają swoich bogów, swoją sztukę i swoje religie ${ }^{40}$.

\footnotetext{
38 Tamże, s. 109.

39 Zob.: „Ludzi widywał osamotniony misjonarz jedynie w niedzielę, kiedy regularnie udawał się do kościoła, a nawet czasem wygłaszał kazania w zastępstwie niezbyt gorliwego angielskiego pastora. Ale choć w swej dawnej parafii szczerze lubił kazać pośród okolicznych wieśniaków i tkaczy, tu, wobec dość obojętnego na sprawy wiary zgromadzenia bogatych kupców, znużonych chorowitych dam i goniących za uciechami młodych urzędników czuł się obco i był onieśmielony" (H. Hesse, Robert Aghion, s. 111).

40 Tamże, s. 106.
} 
Szczera religijność Aghiona przełamuje się ku jakiejś innej formie:

Na każdym kroku uderzały go oznaki religijności. W Londynie z okazji największych uroczystości kościelnych nie można zetknąć się z taką pobożnością, jaką tu dostrzegał w każdym zaułku i każdego dnia; wszędzie znajdowały się świątynie i święte wizerunki, modlono się i składano ofiary, odprawiano uroczyste pochody i ceremonie, wszędzie napotkać można było pokutników i kapłanów. Ale któż by zdołał połapać się $\mathrm{w}$ tym zamęcie różnych religii? Byli tu bramini i mahometanie, czciciele ognia i buddyści, słudzy Sziwy i Kriszny, jedni nosili turban, inni mieli czaszki gładko ogolone, oddawali część wężom albo świętym żółwiom. Gdzie był bóg, któremu służyli wszyscy ci zbłąkani? Jak wyglądał ten bóg i który spośród mnóstwa kultów był najstarszy, najbardziej święty i czysty? Tego nikt nie wiedział, samym Hindusom zaś było to zupełnie obojętne; kto nie był zadowolony z wiary ojców, przyjmował inną albo wyruszał w pokutnej szacie, by znaleźć lub zgoła stworzyć nową religię. W małych miasteczkach stawiano pokarm bogom i duchom, których imion nikt nie znał, a wszystkie te setki obrzędów, świątyń i kapłanów żyły spokojnie obok siebie, zwolennikom jednej wiary nigdy nie przychodziło do głowy by nienawidzić się lub mordować innych, jak to bywało w krajach chrześcijańskich. Niektóre praktyki zresztą miały w sobie wiele uroku, na przykład gra na flecie i subtelne ofiary z kwiatów, twarze wyznawców zaś wyrażały często takie ukojenie i tchnęły tak pogodnym blaskiem, jakiego na próżno szukać u Anglików. Piękny i święty zdaniem Aghiona był też ściśle przestrzegany przez Hindusów zakaz zabijania zwierząt $[\ldots]^{41}$.

Sam Hesse podobne zauroczenie przeżył w dzieciństwie. W tekście Moja wiara (1931) pisał:

W porównaniu z tym jakże ciasnym chrześcijaństwem, z mdławymi wersetami modlitw, z tymi najczęściej nudnymi pastorami i kaznodziejami świat religii hinduskiej był zaiste o wiele bardziej kuszący. Tutaj nie naprzykrzało mi się nic dobrze znanego, tu nie unosiła się atmosfera trzeźwej szarości ambon i pietystycznych kręgów biblijnych, tu otwierała się przestrzeń dla mej wyobraźni bez sprzeciwu przyjmowałem pierwsze przesłania, jakie kierował do mnie świat Indii: miał oddziaływać na mnie przez całe życie ${ }^{42}$.

To, co odczuwa Aghion, jest tamtym dziecięcym zachwytem przeniesionym w świat Indii - w swoje "środowisko naturalne".

We śnie ujrzał Aghion, jak bogowie mieszają się ze sobą. Bóg Ojciec, który zrazu piętnował bezwstydne rzeźby na hinduskiej świątyni uległ przemianie, „miał teraz trzy głowy i sześcioro rąk, a zamiast nieco nieśmiałej

41 Tamże, s. 112-113.

42 H. Hesse, Moja wiara, s. 69. 
i bezradnej powagi na trzech twarzach rysował się wyniosły, zadowolony uśmiech, zupełnie taki sam, jaki miewali często na wizerunkach bogowie hinduscy" ${ }^{\prime 3}$. Ten właśnie Bóg Ojciec wszedł do pogańskiej świątyni, a rzeźbione bożki pogańskie, które ożyły, udały się do kościoła. Nie da się uchylić zasłony - duchowość okazuje się płynna, a słowa, którymi dysponuje Europejczyk, mogą wprawdzie pomóc uporządkować pojęciowo świat przyrody, ale nie bardzo nadają się do kolonizowania świata duchowego (to dlatego Aghion nie był w stanie przystąpić do pracy misyjnej ${ }^{44}$ ).

Ów sen przyśnił się misjonarzowi wkrótce po tym, jak zakochał się w młodej Hindusce Naissie, ujrzanej przypadkiem w wiejskiej chacie - schronił się tam przed ulewnym deszczem. Pokazał mu jego bezradność w obliczu misjonarskiego zadania, którego się podjął. Aghion postanawia ożenić się z Naissą, wybiera się nawet do jej rodziców, by prosić ich o rękę córki. Po drodze widzi ukochaną - idzie zaczerpnąć wody ze źródła, ale udaje, że go nie zna. Dopiero obdarowana prezentem staje się bardziej przychylna. Kiedy oboje zbliżają się do domu, na spotkanie wychodzi im druga Naissa - ta prawdziwa; dziewczyna z dzbanem była jej siostrą, trochę młodszą, ale w oczach Aghiona identyczną. Młodzieniec nie wie, którą z nich kocha. Jego miłość okazała się ułudą, pragnieniem, które wybiera przypadkową piękność, osiada na powierzchni, zadowalając się widokiem, nie umiejąc przeniknąć głębiej.

Hessego interesował proces o kierunku odwrotnym do tego, który wyznacza imperialna ekspansja. $W$ tekście recenzyjnym do mów Buddy (w roku 1921) pisał:

Duchowa fala z Indii, która do Europy - a zwłaszcza do Niemiec - dotarła już w minionym stuleciu, teraz jest powszechnie odczuwana i dla wszystkich widoczna; niezależnie od tego, co kto sądzi o Tagore i Keyserlingu, tęsknota Europy za duchową kulturą dawnego Wschodu przybrała ogromne wręcz rozmiary.

Mówiąc zaś w sposób właściwy psychologii: Europa, w której zaznaczają się wielorakie symptomy rozkładu, zaczyna odczuwać, że nadmierna jednostronność jej kultury duchowej (wyrażającej się najjaskrawiej w zaawansowanej specjalizacji poszczególnych gałęzi wiedzy) wymaga korektury, odświeżenia, które

\footnotetext{
43 H. Hesse, Robert Aghion, s. 120.

44 Zob.: „Nie próbował natomiast jeszcze przy takiej okazji mówić o Bogu. Wydawało mu się to przedwczesne, a ponadto trudne i niemal niewykonalne, gdyż nie znajdował żadnych hinduskich odpowiedników dla wszystkich potocznych zwrotów wiary chrześcijańskiej. Ponadto czuł, że nie ma prawa narzucać się tym ludziom jako nauczyciel i nawoływać do tak poważnej zmiany $\mathrm{w}$ ich życiu, zanim zdoła to życie dobrze poznać i nauczy się żyć oraz rozmawiać z tubylcami niejako na tej samej płaszczyźnie" (tamże, s. 115).
} 
przybędą z przeciwnego bieguna. Ta powszechna tęsknota dotyczy nie tylko nowej etyki czy nowego sposobu myślenia, dotyczy również kultywowania tych wszystkich funkcji psychicznych, które nasza intelektualna duchowość zaniedbała. A zatem ta powszechna tęsknota dotyczy nie tyle Buddy czy Laozi, ile jogi. Przekonaliśmy się bowiem, że człowiek może rozwinąć swój intelekt do tego stopnia, iż zdolny on jest do nader zdumiewających wyczynów, a mimo to nie stanie się panem swej duszy ${ }^{45}$.

W Robercie Aghionie Hesse opowiada o spontanicznych narodzinach tej tęsknoty. Nie bez znaczenia jest fakt, że narodziny te mają miejsce w Indiach rozumianych w kategoriach geograficznych i konkretno-zmysłowych. Stworzone są one z doznań, wrażeń, obserwacji, jakie udostępniła pisarzowi podróż z 1911 roku. Widzimy materię doświadczenia, która w innych tekstach gdzieś wyciekła; zostało z niej to, co dało się wlać w wyraziste przykłady i wpisać w porządek narzucony przez filozofującą myśl. Samo „przebywanie wśród ludów Azji" pozostaje niezaspokojoną tęsknotą: tubylcy są jedynie obrazem (a może należałoby raczej powiedzieć - krajobrazem) tego, co przybyszowi kojarzy się z "duchowością", „prostotą", ale mają w sobie wyraźne rysy przyziemności, które czynią te pojęcia bardziej wielowymiarowymi.

Cała twórczość Hessego ma za swój przedmiot rozwój wewnętrzny; odzwierciedla też ścieżki duchowej biografii autora. Może się wydawać, że czerpie z tradycji Bildungsroman, ale przeformułowuje ją na własną modłę. Chodzi w nich o sam proces poszukiwania planu dla wyrażenia tego, co nie poddaje się werbalizacji, o wskazanie obszaru płynnych sensów. O takiej naturze sensu poucza zapamiętany w dzieciństwie obraz:

tańczący indyjski bożek - ten z oszklonej, pełnej skarbów szafy dziadka - nie był zawsze taki sam, nie miał stale jednakowego oblicza, nie tańczył ciągle jednego tańca. Czasami bywał bożkiem, osobliwą i nieco pocieszną figurą, jakie w dalekich, niepojętych krajach rzeźbiły i czciły dalekie i niepojęte ludy. Innym razem stawał się rzeczą zaklętą, pełną znaczeń, choć bezimienną - przejmującą grozą, żądną ofiar, złośliwą, surową, zawodną, szyderczą; wydawało się, że podpuszcza mnie, żebym go wyśmiał, a potem się za to zemści. Potrafił zmieniać spojrzenie, chociaż zrobiono go z żółtawego metalu, czasami spoglądał nieco krzywo, zezem. O innej znowu godzinie stawał się wyłącznie symbolem, ani brzydkim, ani pięknym, ani śmiesznym czy strasznym - lecz prostym, starym i niewymyślnym, jak znak runiczny, jak kępka mchu na skale, jak rysunek na kamyku. Ukryty poza jego formą, poza twarzą i postacią mieszkał bóg, będący dla mnie wcieleniem nieskończoności, którą już wtedy znałem, choć pozbawioną imienia; jako chłopiec szanowałem ją nie mniej niż w późniejszych latach,

${ }^{45}$ H. Hesse, Moja wiara, s. 33. 
gdy nazywał ją Śiwą, Wisznu, Bogiem, Życiem, Brahmanem, Atmanem, Tao czy Wieczną Matką. To był ojciec i matka, kobieta i mężczyzna, Słońce i Księżyc razem wzięte ${ }^{46}$.

Okazuje się, że patrzenie na Wschód nie polega na tym, że zwraca się głowę $\mathrm{w}$ tym kierunku i wbija wzrok w przestrzeń przed sobą. Spojrzenie może krążyć po różnych obszarach i epokach - tak jak dzieje się to w Podróży na Wschód (pisał ją Hesse między rokiem 1930 a 1931):

Zmierzaliśmy na Wschód, ale wyruszaliśmy także w średniowiecze lub w Złoty Wiek; przeciągaliśmy przez Italię lub Szwajcarię, niekiedy jednak spędzaliśmy noc w X stuleciu i bawiliśmy gościnnie u patriarchów i wróżek ${ }^{47}$.

Bohaterowi (ukrytemu pod inicjałami $\mathrm{HH}$ ) towarzyszą postacie o różnej proweniencji, także te znane z innych utworów Hessego. Wszyscy są członkami tajnego Związku; należą do niego także myśliciele, artyści - „Zaratustra, Laozi, Platon, Ksenofont, Pitagoras, Albert Wielki, don Kichot, Tristram Shandy, Novalis, Baudleaire [...]" 48. Jeśli o Wschód tu chodzi, to o taki, który synchronizuje z duchowością możliwą do odnalezienia w sobie:

[N]asz Wschód był przecież nie tylko jakimś krajem czy pojęciem geograficznym, lecz również ojczyzną i młodością duszy, znajdował się wszędzie i nigdzie, był jednością wszystkich czasów ${ }^{49}$.

Nie można jednak twierdzić, że podróż do Indii/Indochin odbyta w roku 1911 nie była ważna - inaczej nie przypominałby o niej jedenaście czy pięćdziesiąt lat później, nie włączałby jej w retorykę obecności, wzmacniającą siłę wyrażanych przez siebie opinii. Tamta podróż ukazała „naturalne środowisko" zapamiętanych z dzieciństwa znaków Orientu i pozwoliła głęboko doświadczyć tego, co w zasadzie już wiedział: smak owoców południowych, zapach kadzideł, wejście w przestrzeń palmowych plaż i kolorowych świątyń samo w sobie nie prowadzi do „autentycznego ducha Indii” - duchowość nie jest kwestią miejsca geograficznego. Tę podróż pisarz interpretował jako potrzebny etap drogi ku odkryciu własnych form duchowości.

Osobista wizja Indii, którą Hesse pielęgnował, z czasem nabierze wymiaru społecznego, dostarczając materii dla wyobraźni późniejszych podróżników. Do tych Indii będą jechali marzyciele-kontestatorzy, czytelnicy Podróży na Wschód i Siddharthy. Nie przeszkodzi im to, że książki te ukazują Orient

\footnotetext{
46 H. Hesse, Dzieciństwo czarodzieja, s. 13.

47 H. Hesse, Podróż na Wschód, przeł. J. Prokopiuk, Warszawa 1991, s. 20.

48 Tamże, s. 35.

49 Tamże, s. 21.
} 
umowny, o topografii wyraźniej zarysowującej przestrzeń duchową niż fizyczną. W biografiach kontrkulturowych podróżników uobecnią się przestrzenie, które autor powołał do życia i utrwalił w literackich obrazach. Ich sposób czytania Hessego rządził się własnymi prawami. W roku 1970 germanista Egon Schwartz w piśmie wydawanym w Stanach Zjednoczonych pod auspicjami Modern Language Association skomentował to w ten sposób:

Niemiecki autor Herman Hesse 1877-1962) nagle stał się popularny w Ameryce. Jego pseudoinyjska powieść Siddhartha w ciągu jednego roku (1967) sprzedała się w 100000 egzemplarzy. Mistyczno-psychoanalityczne dzieło Demian czyta się na lekcjach angielskiego w postępowych szkołach. Rzecznicy studentów na uniwersytetach posługują się cytatami z pedagogicznej powieści Gra szklanych paciorków, by wesprzeć swą wizję przyszłej edukacji w kraju. Dzieje starzejącego się intelektualisty rozdartego między kulturą klasy średniej i demimonde z Wilka stepowego stały się przedmiotem czci przysługującej wielkim dziełom literatury. [...] Osobliwość tego zjawiska widać, gdy zestawi się socjologiczne początki kultu Hessego w Ameryce z ich niemieckim przeciwieństwem. Nie trzeba pracy detektywa, by stwierdzić, że wyznawcami tej mody są hipisi, wyalienowani i młodzi radykałowie dający się określić mianem „Amerykańskiego ruchu młodych" ${ }^{50}$.

Profesor Schwartz pisał te słowa, gdy dobrze znana już była książka Outsider młodego pisarza Colina Wilsona wydana w 1956 roku. W Outsiderze Wilson omawiał różne literackie ekspresje idei wykraczania poza społeczeństwo, a Hessego ukazał jako jednego ze swych bohaterów. Pisał też kilka lat po opublikowaniu dość prowokacyjnego tekstu Timothy'ego Leary'ego i Ralpha Metznera. W roku 1962 ci psycholodzy-eksperymentatorzy na łamach czasopisma "Psychodelic Review” dowodzili, że Hesse ,jest znakomitym przewodnikiem po doświadczeniu psychodelicznym i jego praktycznym zastosowaniu. Przed każdą sesją LSD należy czytać Siddharthę i Wilka Stepowego" 51.

Książki Hessego zawierały jakoby wyraźny instruktaż - mówiły o tym, jak przejść przez „okna percepcji”:

Jeśli więc macie problem ze zintegrowaniem swych wizji z płaską rutyną życia codziennego, studiujcie Podróż na Wschód. Odnajdźcie swój krąg magiczny. Członkowie Związku czekają na was wszędzie. Dalsze doświadczenie psycho-

50 E. Schwarz, Hermann Hesse, the American Youth Movement, and Problems of Literary Evaluation, „PMLA" 1970, vol. 85, nr 5, s. 997 i 978.

51 T. Leary, Poeta przestrzeni wewnętrznej, w: T. Leary, Polityka ekstazy, przeł. R. Palusiński, D. Misiunia, Kraków 1998, s. 162 (tekst oryginalny dwojga autorów: T. Leary Timothy, R. Metzer Ralph, Poet of the Interior Journey, "Psychedelic Rieview” 1962, nr 2). 
deliczne pomoże wam uporać się z problemem języka i komunikacji, wasze myśli i uczynki nabiorą twórczej złożoności, kiedy dowiecie się, jak bawić się interdyscyplinarnymi symbolami, wielopoziomowymi metaforami. Grą szklanych paciorków ${ }^{52}$.

Doświadczenie medytacyjne ukazane w Siddharcie przepisywali na własną modłę: "Ci z was, którzy mieli kiedyś doświadczenia psychodeliczne, z pewnością rozpoznają tę wizję Gowindy jako klasyczny przykład działania LSD" 53 (chodzi tu o wspomnianą scenę pocałunku, który Gowinda składa na czole Siddharthy). Wprawdzie nie znaleziono bezpośrednich dowodów na to, że Hesse wspomagał proces pisarski substancjami o działaniu narkotycznym, ale Siddhartha, Wilk Stepowy, Podróż na Wschód, Gra szklanych paciorków pozostały dla badaczy z kręgu „Psychedelic Review” tekstami ukazującymi proces poszerzania świadomości w czasie podróży narkotycznych.

Okazało się, że mostami, które Hesse przerzucił między Wschodem a Zachodem można podróżować na wiele sposobów. Z czasem Hessowskie „przewodniki", ukazujące jak uczynić podróż formą nadawania życia, służące niektórym jako używka dla wyobraźni, zaczęły funkcjonować jak swoiste idiomy wyrażające pewien całościowy sens. Przejmują je podróżnicy XXI wieku tacy, jak Max Cegielski, który w książce Masala pisze o swoim bohaterze (autorskim alter ego):

Hermann Hesse podczas swojej podróż na Wschód bał się, że Indie go zmienią. Nie chciał się poddać wpływowi Wschodu, dlatego na wszelki wypadek unikał spotkań z joginami i różnymi guru ${ }^{54}$.

Czy należy korygować to drobne przesunięcie geograficzne i dowodzić, że właściwie Hesse nie był w Indiach? Czy dodawać, że „hindufob”, który pasowałby do tej charakterystyki, to Carl Gustaw Jung (nie tylko był w miejscu geograficznym, nazywanym przez nas Indiami, ale i żywił wspomniane lęki)? To idiomatyczne użycie podróży na Wschód dowodzi, że obecnie obaj - zarówno Hesse, jak i Jung - symbolizują uogólnioną postawę ludzi, którzy niegdyś posiedli duchową podróż do Indii. Bez sensu byłoby więc utyskiwanie, że popularność pewnych symboli powoduje opróżnianie ich z sensów (to stwierdzenie pojawia się w pracach krytyków kultury na tyle często, że stało się banalne). Te jakoby puste symbole współtworzą filtr, przez który patrzymy na rzeczywistość. Wymienne stosowanie imion, nazw czy obrazów

\footnotetext{
52 Tamże.

53 Tamże, s. 153.

54 M. Cegielski, Masala, Warszawa 2008, s. 8.
} 
wskazuje na mechanizm użycia tych symboli - na to, w jaki sposób tworzony jest symboliczny wymiar praktyk kulturowych.

Wspominając Hessego, Cegielski zaznacza, że zna ogólne konotacje toposu drogi do Indii i przejmuje jego dziedzictwo. Wie, że sam pomysł wydawać się może dość wyświechtany - wyruszając w drogę sięga po gotowy pakiet sensów, które może jedynie owinąć bibułką ironii. Zresztą niektóre elementy w zastanawiający sposób pasują do jego własnej biografii (bohater wybiera się do Indii po odbyciu terapii w Ośrodku Leczenia Terapii i Rehabilitacji Uzależnień). Narkotyki, podróż do Indii, książki Hessego to motywy sygnujące kontrkulturowe podróże, poprzedzające wyjazd Maxa o jakieś trzy-cztery dekady. Gest wyruszenia nie jest jednak skierowany przeciw społeczeństwu i jego zastanym strukturom; wręcz przeciwnie, Max i jego dziewczyna Zosia realizują marzenie rodziców:

Jego dziewczyna i mamusie, które ich odprowadzały, były strasznie zdenerwowane. Jemu więc nie wypadało. [...] Mamusie przekroczyły już pięćdziesiątkę. Wielu znajomych z ich pokolenia podróżowało na Wschód, ale one akurat nie. Wyluzowane, ale nie do tego stopnia, żeby krążyć gdzieś po dalekich światach. Obydwie bez mężów, zamożne, udzieliły finansowego wsparcia wyprawie. Może dzieci zrobią to, na co one nigdy by się nie odważyły. Choć lot samolotem do Delhi to nie wyprawa przez serce Afryki ${ }^{55}$.

Tego rodzaju „kontynuacja tradycji kontrkultury” zabija sam pomysł ostrze sprzeciwu traci swój cel. Bohatera uratować może autoironiczne podejście do własnego przedsięwzięcia:

Nasz bohater, podobnie jak wielu innych europejskich młodych i nadętych przemyśliwaczy, bardzo chciał się zmienić. Zakończyć proces, który rozpoczął ponad rok temu. Może właściwie nie tyle zmienić, co w ogóle stworzyć się na nowo. [...] Uciekał więc do Indii, a uciekając, cały czas prześcigać samego siebie. Uciekał od uciekania. Postanowił więc udawać, że to nie on jedzie do Indii. Zacznie być sobą, jak wróci ${ }^{56}$.

To jest ucieczka inna niż ta, którą przedsięwziął Hesse. On, jak wiemy, uciekał od Europy (i od osobistych problemów), ale podróż miała pozytywnie wartościowany kierunek, była to jednocześnie ucieczka od i podróż do.

Dzisiejszy podróżnik, deklarujący ucieczkę od uciekania, wypracowuje własne strategie budowania magicznych mostów. Zna wszelkie możliwe topografie przestrzeni - poznał je w porządku symulakrycznym; spogląda

$\begin{array}{ll}55 & \text { Tamże. } \\ 56 & \text { Tamże, s. 7-8. }\end{array}$ 
na nie tak, że różne plany nakładają się na siebie. Zna też różne projekty podróży i wie, że dla niego decydujący będzie nie tyle wybór określonego projektu, ile modus, w jakim go zaktualizuje.

Cegielski jako autor Masali znajduje się na początku procesu tworzenia własnych magicznych mostów - ich zarysy będą wyraźniejsze w jego kolejnych książkach. Masala, jak dowodzi jej autor w posłowiu do trzeciego wydania, to pewien etap, a zarazem źródło kolejnych opowieści o podróżach. W relacji z Pakistanu Pijani Bogiem ironia ustąpi miejsca ciekawości. Autor nie będzie się już uciekał do narracji trzecioosobowej - opowie o własnych poszukiwaniach, o próbie przeniknięcia mistycyzmu islamskiego i zajrzenia „za kulisy mistycznych spektakli" ${ }^{57}$. To nie on jednak będzie bohaterem opowieści - przyzna to miejsce bębniarzom sufickim, braciom Mittu i Gundze, ich rodzinom i innym osobom, które mogą mu wskazać te kulisy. Jeśli zdystansuje się wobec własnego doświadczenia, to po to, by jego znaczenie zobaczyć w szerszym układzie ${ }^{58}$.

Kiedy weźmie na siebie rolę kronikarza buntowników i zestawi ich leksykon, otworzy go rozdziałem o bitnikach; będzie pamiętać o tym, że to Allen Ginsberg zapoczątkował „tradycję powojennych wyjazdów artystyczno-duchowych (podobne praktykowane były od pojawienia się na subkontynencie Portugalczyków pod koniec XV wieku)" 59. W jego czasach problem polega nie na tym, jak uczynić podróż formą nadawania sensu życiu, ale raczej na tym, jak nadać sens podróży - jak odzyskać świeżość jej sensów, wiedząc, że nie będzie się już ani podróżującym do Indii Hessem, ani nawet Ginsbergiem podróżującym z książką Hessego. Z magicznego mostu, który powstaje, wciąż jednak widać szlaki ich podróży.

57 M. Cegielski, Pijani Bogiem, Warszawa, s. 60.

58 Zob.: „Dawniej kontestator mógł zostać punkiem, teraz w wachlarzu propozycji pojawiła się kolejna: przejdź na islam! Propozycja najwyraźniej ciekawa, bo oto dawni kontestatorzy coraz chętniej przybierają palestyńskie czy irackie szaty ofiar systemu i idą modlić się do meczetów. Znaleźli nowe ujście dla swojego buntu, zagubieni w świecie otrzymali świeżo wymalowany drogowskaz. [...] Cała kontrkulturowa energia skupiła się na walce z szatanem konsumpcji i świeckości. Krytykując fundamentalizm zachodni, po cichu sympatyzując z muzułmańskim, sam zaczynałem wierzyć w nieuchronną wojnę cywilizacji. Kiedy wróciłem do Pakistanu, byłem już prawie ortodoksem, przekonanym, że Wschód z Zachodem nigdy się nie spotkają. Wierzyłem, że „ex oriente Lux" (M. Cegielski, Pijani Bogiem, s. 90).

59 M. Cegielski, Leksykon buntowników, Warszawa 2013, s. 17. 


\section{Hermann Hesse and His Magical Bridges \\ Summary}

This article discusses Hermann Hesse's short trip to Asia in 1911 and its peculiar symbolism. The trip created an area of references which he used in his writing. He transformed experience of this trip and expectations connected therewith artistically and philosophically, building a special variation of the topos of the way to the East. This topos was widely employed in the times of counterculture, which had transformed it in its own way, but it is still vital today.

Keywords: journey, Asia, East, topos, Herman Hesse 